\title{
Synthesis of Novel 6-(Substituted benzyl)imidazo[2,1-b][1,3]thiazole Catalyzed by Polystyrene-Supported Palladium(II) Ethylenediamine Complex
}

\author{
Mohammad Bakherad,* Ali Keivanloo, Bahram Bahramian and Taghi A. Kamali \\ Faculty of Chemistry, Shahrood University of Technology, Shahrood, Iran
}

\begin{abstract}
O complexo etilenodiamina paládio(II) suportado em polímero, [PS-en-Pd(II)], é um catalisador altamente ativo, usado para a reação de acoplamento de Sonogashira entre um iodeto de arila e brometo de 2-amino-3-(2-propinila)1,3-tiazólio, 3. Esse catalisador heterogêneo de paládio é eficiente, estável e reciclável. A reação do composto 3 com vários iodetos de arila, $\mathbf{4 a - f}$, na presença do complexo [PS-en-Pd(II)] leva à produção dos 6-(benzil)imidazo[2,1-b][1,3]tiazóis, 5a-f.
\end{abstract}

The polymer-supported palladium(II) ethylenediamine complex, [PS-en-Pd(II)], is a highly active catalyst that could be used for the Sonogashira coupling reaction between an aryl iodide and 2-amino-3-(2-propynyl)-1,3-thiazolium bromide, 3 . This heterogeneous palladium catalyst is efficient, stable, and recyclable. Reaction of compound $\mathbf{3}$ with various aryl iodides, $\mathbf{4 a - f}$ in the presence of the [PS-en-Pd(II)] complex leads to the production of the 6-(substituted benzyl) imidazo[2,1-b][1,3]thiazoles 5a-f.

Keywords: Sonogashira coupling, heterogeneous catalyst, aryl iodides, imidazothiazoles

\section{Introduction}

The Sonogashira cross-coupling of aryl halides and terminal alkynes or arylenes is a useful tool for the synthesis of alkyl-aryl and diaryl-substituted acetylenes. ${ }^{1}$ Functionalized alkynes are important building blocks for the synthesis of biologically active molecules and, surprisingly, are common structural features of natural products that have been isolated from plants and marine organisms or synthetic drugs. ${ }^{2}$ Therefore, the Sonogashira reaction is frequently used as a key step in the synthesis of the pharmaceuticals such as the enediyne antibiotics or the contraceptive pill. ${ }^{3}$

The reaction is generally carried out in organic solvents such as benzene, toluene, THF, DMF, and dioxane. It requires a base, which is usually an amine such as triethylamine, diethylamine, and diisopropylethylamine. The most widely used catalysts are $\mathrm{Pd}\left(\mathrm{PPh}_{3}\right)_{2} \mathrm{Cl}_{2}$ and $\mathrm{Pd}\left(\mathrm{PPh}_{3}\right)_{4}$ in conjunction with copper(I) iodide. ${ }^{4}$

To extend the Sonogashira reaction for fine chemical applications, numerous studies have been reported in the literature over the last 15 years including the use of a phase transfer agent, ${ }^{5}$ reaction in aqueous media or without solvent, ${ }^{6}$ reaction in ionic liquids, ${ }^{7}$ copper-free

*e-mail: m.bakherad@yahoo.com; mbakherad@shahroodut.ac.ir versions, ${ }^{8}$ and the use of promoters such as $\mathrm{Zn}, \mathrm{Mg}, \mathrm{Sn}$, and $\mathrm{R}_{4}$ NI. ${ }^{9}$

While these examples contributed to the improvement of the Sonogashira coupling reaction, they remained based on a homogeneous palladium complex catalyst, which makes the separation and recovery of the catalysts tedious, if not impossible, and might result in unacceptable palladium contamination of the products. A way to overcome these difficulties would be the use of a heterogeneous palladium catalyst. Although a great deal of effort has been made to carry out the coupling reaction using immobilized palladium catalysts, ${ }^{10}$ what seems to be lacking is the efficiency of the catalytic systems. It is obvious that the heterogeneous catalytic systems generally exhibit lower activities than the homogeneous ones, and the activity of the catalysts decreases gradually in the recycled systems. To overcome this limitation, a novel methodology for creating insoluble and highly active catalysts is needed. Our approach was guided by three imperatives: $(i)$ the support should be easily accessible; (ii) starting with readily available and cheap reagents; and (iii) the ligand anchored on the support should be air stable at room temperature, which should allow its storage in normal bottles with unlimited shelf life.

To date, a few palladium complexes on functionalized polystyrene support have been prepared and successfully used in organic reactions. ${ }^{11}$ However, to the best of our 
knowledge, there has been no examples involving arylation of imidazo[1,3]thiazole by [PS-en-Pd(II)] catalyzed (Sonogashira coupling) reactions described to date.

The imidazo[2,1-b][1,3]thiazole skeleton has been used as anthelmintic agents, anti-hypertensives, antiinflammatories, immunosuppressive agents, fungicides, herbicides, antitumor agents, and cardiotonic agents. ${ }^{12}$

Considering the potent bioactivities of compounds possessing an imidazothiazole core, the development of a new strategy to synthesize imidazo[2,1-b][1,3]thiazole derivatives efficiently attracted our attention.

In this paper we wish to report the synthesis of the polystyrene-supported palladium(II) ethylenediamine complex, abbreviated as [PS-en-Pd(II)], ${ }^{13}$ and its catalytic properties in the Sonogashira coupling reaction for the synthesis of 6-(substituted benzyl)imidazo[2,1-b][1,3]thiazoles. The supported catalyst could be reused for several times without a significant degradation in its catalytic activity.

\section{Results and Discussion}

We used the well known chloromethylated polystyrene cross-linked with $2 \%$ divinylbenzene as support because it is flexible enough and allows metallic atoms to graft on it via the ligands that are attached to the polymer beads. Reaction of the polystyrene resin with ethylenediamine in acetonitrile under reflux and the subsequent reaction of the aminated polystyrene with a solution of $\left[\mathrm{PdCl}_{2}\left(\mathrm{C}_{6} \mathrm{H}_{5} \mathrm{CN}\right)_{2}\right]$ in ethanol gave the polymer-supported palladium(II) complex catalyst 1 (Scheme 1).

Successful functionalization of the polymer was confirmed by elemental analysis. The $\mathrm{N}$ content of the resin

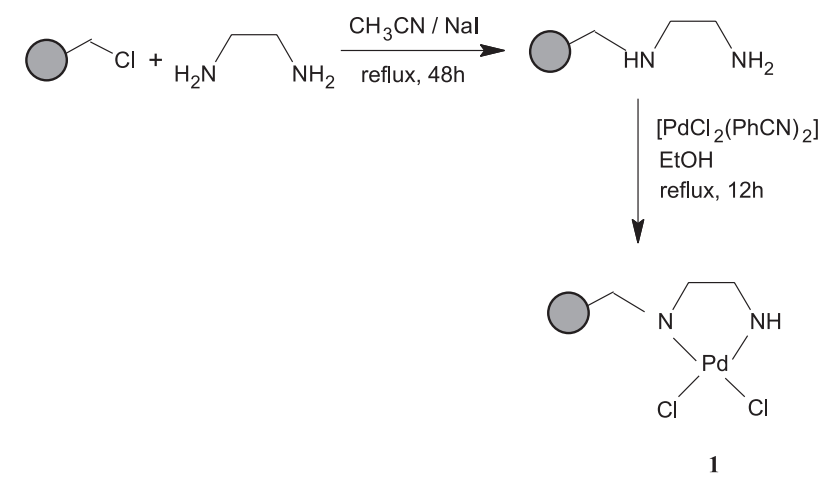

Scheme 1. Polystyrene-supported palladium(II) ethylenediamine complex $\mathbf{1 .}$

was found to be $2.42 \%\left(0.82 \mathrm{mmol} \mathrm{g}^{-1}\right)$, which indicates that only $58 \%$ of the total chlorines were substituted by amine. The metal loading of the polymer-supported palladium complex, which was determined by neutron activation analysis (NAA), was found to be $4.35 \%\left(0.41 \mathrm{mmol} \mathrm{g}^{-1}\right)$. In the IR spectrum of the polymer-bound ethylenediamine, the sharp $\mathrm{C}-\mathrm{Cl}$ peak (due to the $-\mathrm{CH}_{2} \mathrm{Cl}$ groups) at $1264 \mathrm{~cm}^{-1}$ in the starting polymer was practically omitted or was seen as a weak band after introduction of ethylenediamine and palladium onto the polymer. The various IR frequencies for the catalyst were assigned as $(\mathrm{Pd}-\mathrm{N}) c a .506 \mathrm{~cm}^{-1},(\mathrm{C}-\mathrm{N})$ ca. $1100 \mathrm{~cm}^{-1}$, and $(\mathrm{N}-\mathrm{H}) c a .3400 \mathrm{~cm}^{-1}$.

In order to evaluate the catalytic activity of the polymersupported palladium(II) ethylenediamine complex, [PS-en$\operatorname{Pd}(\mathrm{II})]$, the Sonogashira coupling reactions of 2-amino3-(2-propynyl)-1,3-thiazolium bromide 3 with the aryl iodides $4 \mathbf{4}$-f were studied (Scheme 2). The reactions were performed under conditions similar to those used in the corresponding homogenous reactions.

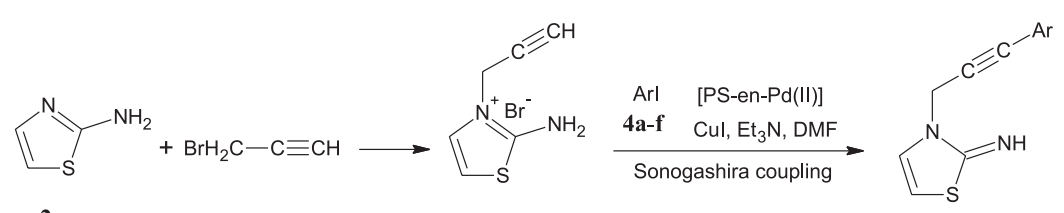

2

3

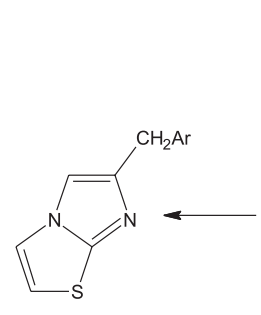

5a-f

a: $\mathrm{Ar}=2-\mathrm{NO}_{2}-\mathrm{C}_{6} \mathrm{H}_{4}^{-}$

b: $\mathrm{Ar}=4-\mathrm{NO}_{2}-\mathrm{C}_{6} \mathrm{H}_{4}-$

c: $\mathrm{Ar}=2-\mathrm{CH}_{3}-4-\mathrm{NO}_{2}-\mathrm{C}_{6} \mathrm{H}_{3}-$

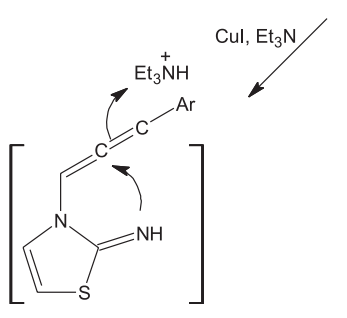

$[\mathbf{A}]$

Scheme 2. A plausible mechanism for the formation of 6-(substituted benzyl)imidazo[2,1-b][1,3] thiazoles at room temperature.

d: $\mathrm{Ar}=2-\mathrm{Cl}-4-\mathrm{NO}_{2}-\mathrm{C}_{6} \mathrm{H}_{3}-$ e: $\mathrm{Ar}=4-\mathrm{Cl}-2-\mathrm{NO}_{2}-\mathrm{C}_{6} \mathrm{H}_{3}-$ f: $\mathrm{Ar}=4-\mathrm{Cl}-3-\mathrm{NO}_{2}-\mathrm{C}_{6} \mathrm{H}_{3}-$ 
Mechanistically, the formation of 6-(substituted benzyl) imidazo[2,1-b][1,3]thiazoles involves the following steps (as shown in Scheme 2): (i) standard Sonogashira coupling ${ }^{14}$ and (ii) isomerization to the allenic intermediates ${ }^{15}[\mathrm{~A}]$, which then cyclize to the products $\mathbf{5 a - f}$.

The presence of electron-withdrawing groups such as $-\mathrm{NO}_{2}$, or $-\mathrm{Cl}$ on the aryl iodide was essential for successful reaction. When $p$-iodoanisole or iodobenzene was used as the aryl iodide, Sonogashira coupling did not occur.

For optimization of the reaction conditions, we chose the reaction of 2-amino-3-(2-propynyl)-1,3-thiazolium bromide 3 with 4-chloro-2-nitroiodobenzene $\mathbf{4 e}$ as the model reaction, and the effects of the base, solvent, amount of copper(I) iodide, and the catalyst on the catalytic property of the [PS-en-Pd(II)] complex were examined. The results were tabulated in Table 1 .

Among the bases tested, triethylamine proved to be the most efficient, and among the solvents used, dimethylformamide was the best choice (entry 3 ). Increasing the amount of the palladium catalyst could shorten the reaction time but does not increase the yield (entry 10). Low palladium concentration often prolonged the reaction time and decreased the yield (entries 11 and 12). We also found that with increase in the amount of copper(I) iodide, the reaction yield did not increase (entry 13). No product was obtained under copper-free conditions (entry 14). Copper(I) iodide was found to be an essential co-catalyst.
Subsequently, the reaction of a variety of aryl iodides, 4a-f, with 2-amino-3-(2-propynyl)-1,3-thiazolium bromide $\mathbf{3}$ was studied under the optimal conditions. The reactions had to be carried out under an argon atmosphere, and we had to degas the DMF and triethylamine mixture prior to use. The experimental results were summarized in Table 2. As it could be seen in this table, reaction of the aryl iodides with compound $\mathbf{3}$ proceeded smoothly under very mild conditions, giving the corresponding products in excellent yields.

The stability of [PS-en-Pd(II)] was studied in the repeated Sonogashira coupling reactions. The coupling reaction of 4-chloro-2-nitroiodobenzene 4e with compound $\mathbf{3}$ was chosen as a model substrate to study the catalyst reuse and stability. The catalyst was separated from the reaction mixture after each experiment by filtration, washed with acetonitrile, and dried carefully before using it in the subsequent run. The reaction promoted by the $5^{\text {th }}$ recycled catalyst gave $\mathbf{5 e}$ in $80 \%$ yield (Table 3, entry 5).

This reusability demonstrates the stability of the heterogeneous catalyst. Although no significant change in the activity of the catalyst was observed, we performed analysis of the catalyst after the $5^{\text {th }}$ run in order to determine any change in the catalyst structure. The nature of the recovered catalyst was traced by IR spectroscopy. The results indicated that the catalyst showed no change in its IR spectrum after reuse for several times.

Table 1. Heterocyclization during the Sonogashira coupling of 4-Chloro-2-nitroiodonitrobenzene with compound $\mathbf{3}$ in the presence of several bases, solvents, and amounts of catalyst ${ }^{\mathrm{a}}$

\begin{tabular}{|c|c|c|c|c|c|c|}
\hline Entry & Base & Solvent & {$[$ PS-en-Pd(II)] / mmol } & $\mathrm{CuI} / \mathrm{mmol}$ & time $/ \mathrm{h}$ & Yield / \% \\
\hline 1 & $\mathrm{Et}_{3} \mathrm{~N}$ & Dioxane & 0.02 & 0.1 & 18 & 35 \\
\hline 2 & $\mathrm{Et}_{3} \mathrm{~N}$ & $\mathrm{CH}_{3} \mathrm{CN}$ & 0.02 & 0.1 & 20 & 45 \\
\hline 3 & $\mathrm{Et}_{3} \mathrm{~N}$ & DMF & 0.02 & 0.1 & 16 & 95 \\
\hline 4 & $\mathrm{Et}_{3} \mathrm{~N}$ & $\mathrm{Et}_{3} \mathrm{~N}$ & 0.02 & 0.1 & 20 & 20 \\
\hline 5 & DIEA & DIEA & 0.02 & 0.1 & 18 & 40 \\
\hline 6 & Piperidine & DMF & 0.02 & 0.1 & 15 & 70 \\
\hline 7 & Piperidine & Piperidine & 0.02 & 0.1 & 18 & 25 \\
\hline 8 & Pyridine & Pyridine & 0.02 & 0.1 & 18 & 45 \\
\hline 9 & Pyrrolidine & Pyrrolidine & 0.02 & 0.1 & 24 & 35 \\
\hline 10 & $\mathrm{Et}_{3} \mathrm{~N}$ & DMF & 0.03 & 0.15 & 10 & 92 \\
\hline 11 & $\mathrm{Et}_{3} \mathrm{~N}$ & DMF & 0.01 & 0.05 & 24 & 75 \\
\hline 12 & $\mathrm{Et}_{3} \mathrm{~N}$ & DMF & 0.005 & 0.015 & 24 & 55 \\
\hline 13 & $\mathrm{Et}_{3} \mathrm{~N}$ & DMF & 0.02 & 0.2 & 24 & 87 \\
\hline 14 & $\mathrm{Et}_{3} \mathrm{~N}$ & DMF & 0.02 & 0 & 24 & 0 \\
\hline
\end{tabular}

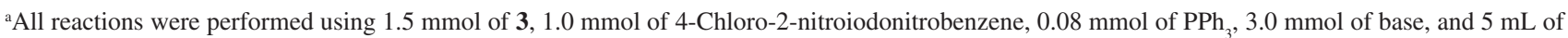
solvent at room temperature. 
Table 2. Melting points and yields of 6-(substituted benzyl)imidazo[2,1- $b]$ $[1,3]$ thiazoles $\mathbf{5} \mathbf{a}-\mathbf{f}^{\mathbf{a}}$

Product

${ }^{\mathrm{a}}$ All reactions were performed using $1.5 \mathrm{mmol}$ of $\mathbf{3}, 1.0 \mathrm{mmol}$ of substituted iodobenzene, $0.1 \mathrm{mmol}$ of CuI, $0.02 \mathrm{mmol}$ of [PS-en-Pd(II)], $3 \mathrm{mmol}$ of $\mathrm{Et}_{3} \mathrm{~N}, 5 \mathrm{~mL}$ of DMF at room temperature.

Table 3. Heterocyclization during Sonogashira coupling of 4-Chloro-2nitroiodobenzene $4 \mathbf{e}$ with compound $\mathbf{3}$ catalyzed by recycled catalyst $\mathrm{t}^{\mathrm{a}}$

\begin{tabular}{lcc}
\hline Entry & Catalyst cycle & Product 5e, yield / (\%) \\
\hline 1 & $1^{\text {st }}$ & 95 \\
2 & $2^{\text {nd }}$ & 92 \\
3 & $3^{\text {rd }}$ & 90 \\
4 & $4^{\text {th }}$ & 87 \\
5 & $5^{\text {th }}$ & 80 \\
\hline
\end{tabular}

${ }^{\mathrm{a}}$ All reactions were performed using $1.5 \mathrm{mmol}$ of $\mathbf{3}, 1.0 \mathrm{mmol}$ of 4-Chloro-2-nitroiodobenzene, $0.1 \mathrm{mmol}$ of $\mathrm{CuI}, 0.02 \mathrm{mmol}$ of [PS-en-Pd(II)], $0.08 \mathrm{mmol}$ of $\mathrm{PPh}_{3}, 3.0 \mathrm{mmol}_{\text {of }} \mathrm{Et}_{3} \mathrm{~N}$, and $5 \mathrm{~mL}$ of DMF at room temperature.
To determine the absolute amount of the palladium species leached into the solution, the crude reaction mixtures were evaporated to dryness and analyzed by NAA. It was shown that less than $0.5 \%$ of the total amount of the original palladium species was lost into the solution during the course of the reaction.

\section{Conclusions}

We developed the reusable heterogeneous catalyst [PS-en-Pd(II)] by reacting the commercially available crosslinked chloromethylated polystyrene with ethylenediamine, and the subsequent reaction of the product thus formed with dibenzonitrile palladium chloride. The catalyst is efficient for syntheses of various 6-(substituted benzyl) imidazo[2,1-b][1,3]thiazoles via Sonogashira coupling reaction of aryl iodides with 2-amino-3-(2-propynyl)-1,3thiazolium bromide 3 . The advantages of our heterogeneous catalytic system over others are as follow: (i) the catalyst could be conveniently prepared from commercially available reagents; (ii) excellent performance and reusability of the catalyst.

\section{Experimental}

All the reagents used were of commercial reagent grade. Chloromethylated polystyrene $(4-5 \% \mathrm{Cl}$ and $2 \%$ cross-linked with divinylbenzene) was a Merck product. The scanning electron micrographs of the catalyst and polymer were taken on an SEM Philips XL 30 instrument. IR spectra were obtained as potassium bromide pellets in the range $400-4000 \mathrm{~cm}^{-1}$ on a Shimadzu Model 460 spectrometer. ${ }^{1} \mathrm{H}$ NMR spectra were recorded on a Bruker BRX 500 AVANCE spectrometer. Elemental analysis was performed on a Thermo Finnigan Flash EA microanalyzer.

\section{Procedure for preparation of polymer-bound ethylenediamine}

In order to functionalize the polymer support with ethylenediamine, we carried out the following procedure: to a $250 \mathrm{~mL}$ round bottom flask equipped with a magnetic bar, and containing $120 \mathrm{~mL}$ acetonitrile, were added chloromethylated polystyrene $\left(1.25 \mathrm{mmol} \mathrm{g}^{-1}\right.$ of $\left.\mathrm{Cl}\right)$, ethylenediamine $(25 \mathrm{mmol})$, and $\mathrm{NaI}(0.13 \mathrm{mmol})$ and the reaction mixture was refluxed for $48 \mathrm{~h}$. The filtrate was then filtered off and washed with $5 \times 40 \mathrm{~mL}$ of $\mathrm{CH}_{3} \mathrm{CN}$, $5 \times 40 \mathrm{~mL}$ of $1: 1 \mathrm{CH}_{3} \mathrm{OH} / \mathrm{K}_{2} \mathrm{CO}_{3}\left(1 \mathrm{~mol} \mathrm{~L}^{-1}\right), 5 \times 40 \mathrm{~mL}$ of $1: 1 \mathrm{CH}_{3} \mathrm{OH} / \mathrm{H}_{2} \mathrm{O}$, and $3 \times 40 \mathrm{~mL}$ of diethyl ether, and subsequently dried in an oven. 
Procedure for preparation of polystyrene-supported palladium(II) ethylenediamine complex $\mathbf{1}$

The functionalized polymer was kept in contact with $100 \mathrm{~mL}$ of ethanol for $30 \mathrm{~min}$. An ethanolic solution of $0.25 \mathrm{~g}$ of $\left[\mathrm{PdCl}_{2}\left(\mathrm{C}_{6} \mathrm{H}_{5} \mathrm{CN}\right)_{2}\right]$ was added to it and the resulting mixture was heated to $50{ }^{\circ} \mathrm{C}$ for $6 \mathrm{~h}$. The bright yellowcolored polymer, impregnated with the metal complex, was filtered, washed thoroughly with ethanol, and finally dried in vacuum at $70^{\circ} \mathrm{C}$ for $24 \mathrm{~h}$.

IR (KBr): $506\left(v_{\mathrm{Pd}-\mathrm{N}}\right), 1100\left(\mathrm{v}_{\mathrm{C}-\mathrm{N}}\right), 3400\left(\mathrm{v}_{\mathrm{N}-\mathrm{H}}\right)$; Anal. Found for [PS-en-Pd(II)]: C, 63.65; H, 5.95; Cl, 1.90; N, 2.42; Pd, 4.35. Anal. Found for recycled [PS-en-Pd(II)]: C, 62.90; H, 5.56; Cl, 1.35; N, 2.34; Pd, 3.90

Synthesis of 2-amino-3-(2-propynyl)-1,3-thiazolium bromide (3)

A mixture of 2-aminothiazole $2(2 \mathrm{~g}, 20 \mathrm{mmol})$ and propargyl bromide $(2 \mathrm{~mL}, 24 \mathrm{mmol})$ in acetonitrile $(10 \mathrm{~mL})$ was heated under reflux for $1 \mathrm{~h}$. The precipitate formed was filtered off and recrystallized from acetonitrile to afford the title compound.

Yield, 95\%; mp 159-160 ${ }^{\circ} \mathrm{C}$; IR (KBr) $v_{\text {max }} / \mathrm{cm}^{-1}: 3300$, 3250,2150 ; ${ }^{1} \mathrm{H}$ NMR $\left(500 \mathrm{MHz}\right.$, DMSO- $\left.d_{6}\right): \delta 3.73(\mathrm{~s}, 1 \mathrm{H}$, $\mathrm{CH}), 5.03\left(\mathrm{~s}, 2 \mathrm{H}, \mathrm{CH}_{2}\right), 7.07$ (d, 1H, CH of thiazole), 7.50 ( d, $1 \mathrm{H}, \mathrm{CH}$ of thiazole), 9.78 (s, $\left.2 \mathrm{H}, \mathrm{NH}_{2}\right) ;{ }^{13} \mathrm{C}$ NMR $(125$ MHz, DMSO- $\left.d_{6}\right): \delta 38.67,76.55,79.16,109.19,130.05$, 168.69; MS m/z $139\left(\mathrm{M}^{+}\right)$. Anal. Calc. for $\mathrm{C}_{6} \mathrm{H}_{7} \mathrm{BrN}_{2} \mathrm{~S}: \mathrm{C}$, 32.89; H, 3.22; N, 12.79; S, 14.63. Found: C, 32.65; H, $3.03 ; \mathrm{N}, 12.55 ; \mathrm{S}, 14.47$.

Syntheses of 6-(substituted benzyl) imidazo[2,1-b][1,3] thiazoles (5a-f)

A mixture of the substituted iodobenzene $4 \mathbf{a}-\mathbf{i}$ (1.0 mmol), [PS-en-Pd(II)] (0.04 g, $0.02 \mathrm{mmol}$ of Pd), $\mathrm{CuI}(0.1 \mathrm{mmol})$, triphenylphosphine $(0.08 \mathrm{mmol})$, and triethylamine ( $3 \mathrm{mmol}$ ) was stirred in DMF $(5 \mathrm{~mL})$ at room temperature under an argon atmosphere. 2-Amino-3-(2propynyl)-1,3-thiazolium bromide 3 ( $0.33 \mathrm{~g}, 1.50 \mathrm{mmol}$ ) was then added and the mixture was stirred at room temperature for 10-18 h. After completion of the reaction, the resulting solution was concentrated in vacuo, and the crude product was subjected to column chromatography using $\mathrm{CHCl}_{3} / \mathrm{CH}_{3} \mathrm{OH}$ (95:5) as the eluent to afford the pure product (Table 2).

\section{6-(2-Nitrobenzyl)imidazo[2,1-b][1,3]thiazole (4a)}

IR (KBr) $v_{\max } / \mathrm{cm}^{-1}: 1520,1340 ;{ }^{1} \mathrm{H}$ NMR $(500 \mathrm{MHz}$, DMSO-d $_{6}$ ): $\delta 4.25$ (s, 2H, $\mathrm{CH}_{2}$ ), 6.95-7.96 (m, 6H, thiazol
\& $\mathrm{ArH}), 8.63$ (s, 1H, CH of imidazole); ${ }^{13} \mathrm{C}$ NMR (125 MHz, DMSO- $\left.d_{6}\right): \delta 35.32,110.46,122.45,124.10,128.93$, 129.82, 130.37, 131.25, 131.98, 134.24, 147.67, 154.56; MS m/z $259\left(\mathrm{M}^{+}\right)$. Anal. Calc. for $\mathrm{C}_{12} \mathrm{H}_{9} \mathrm{~N}_{3} \mathrm{O}_{2} \mathrm{~S}$ : C, 55.59; H, 3.50; N, 16.21; S, 12.37. Found: C, 55.32; H, 3.36; N, $16.40 ; \mathrm{S}, 12.21$.

\section{6-(4-Nitrobenzyl)imidazo[2,1-b][1,3]thiazole (4b)}

IR (KBr) $v_{\max } / \mathrm{cm}^{-1}: 1525,1340 ;{ }^{1} \mathrm{H}$ NMR $(500 \mathrm{MHz}$, DMSO-d $\left.\mathrm{d}_{6}\right): \delta 4.18\left(\mathrm{~s}, 2 \mathrm{H}, \mathrm{CH}_{2}\right), 7.25-8.15(\mathrm{~m}, 6 \mathrm{H}$, thiazol \& $\mathrm{ArH}), 8.31$ (s, $1 \mathrm{H}, \mathrm{CH}$ of imidazole); ${ }^{13} \mathrm{C}$ NMR $(125$ MHz, DMSO- $d_{6}$ ): $\delta 34.78,109.67,122.87,123.05,127.93$, 128.30, 129.87, 130.64, 131.43, 134.08, 148.20, 154.86; MS $m / z 259\left(\mathrm{M}^{+}\right)$. Anal. Calc. for $\mathrm{C}_{12} \mathrm{H}_{9} \mathrm{~N}_{3} \mathrm{O}_{2} \mathrm{~S}$ : C, 55.59; H, 3.50; N, 16.21; S, 12.37. Found: C, 55.37; H, 3.32; N, $16.45 ; \mathrm{S}, 12.18$.

6-(2-Methyl-4-nitrobenzyl)imidazo[2,1-b][1,3]thiazole (4c) IR (KBr) $v_{\text {max }} / \mathrm{cm}^{-1}: 1530,1345 ;{ }^{1} \mathrm{H}$ NMR $(500 \mathrm{MHz}$, DMSO-d $\left.\mathrm{d}_{6}\right): \delta 2.50\left(\mathrm{~s}, 3 \mathrm{H}, \mathrm{CH}_{3}\right), 4.10\left(\mathrm{~s}, 2 \mathrm{H}, \mathrm{CH}_{2}\right), 7.22-$ $8.06(\mathrm{~m}, 5 \mathrm{H}$, thiazol \& $\mathrm{ArH}), 8.14$ (s, $1 \mathrm{H}, \mathrm{CH}$ of imidazole); ${ }^{13} \mathrm{C}$ NMR (125 MHz, DMSO- $\left.d_{6}\right): \delta 21.30,35.74,110.21$, $122.13,122.90,123.65,126.92,130.12,130.65,131.15$, 133.16, 147.43, 155.30; MS m/z $273\left(\mathrm{M}^{+}\right)$. Anal. Calc. for $\mathrm{C}_{13} \mathrm{H}_{11} \mathrm{~N}_{3} \mathrm{O}_{2} \mathrm{~S}: \mathrm{C}, 57.13 ; \mathrm{H}, 4.06 ; \mathrm{N}, 15.37 ; \mathrm{S}, 11.73$. Found: C, 57.31; H, 3.90; N, 15.51; S, 11.61 .

6-(2-Chloro-4-nitrobenzyl)imidazo[2,1-b][1,3]thiazole (4d)

IR (KBr) $v_{\text {max }} / \mathrm{cm}^{-1}: 1525,1340 ;{ }^{1} \mathrm{H}$ NMR $(500 \mathrm{MHz}$, DMSO-d ${ }_{6}$ ): $\delta 4.28$ (s, $2 \mathrm{H}, \mathrm{CH}_{2}$ ), 7.24-8.28 (m, 5H, thiazol $\& \mathrm{ArH}), 8.32$ (s, $1 \mathrm{H}, \mathrm{CH}$ of imidazole); ${ }^{13} \mathrm{C}$ NMR (125 MHz, DMSO- $\left.d_{6}\right): \delta 34.88,109.53,123.20,123.78,128.31$, 130.62, 131.15, 131.85, 132.21, 133.90, 151.10, 155.06; MS $\mathrm{m} / 2,293\left(\mathrm{M}^{+}\right), 295(\mathrm{M}+2)$. Anal. Calc. for $\mathrm{C}_{12} \mathrm{H}_{8} \mathrm{ClN}_{3} \mathrm{O}_{2} \mathrm{~S}$ : C, 49.07; H, 2.75; N, 14.31; S, 10.92. Found: C, 49.29; H, $2.87 ; \mathrm{N}, 14.20 ; \mathrm{S}, 11.02$.

6-(4-Chloro-2-nitrobenzyl)imidazo[2,1-b][1,3]thiazole (4e)

IR (KBr) $v_{\max } / \mathrm{cm}^{-1}: 1520,1340 ;{ }^{1} \mathrm{H}$ NMR $(500 \mathrm{MHz}$, DMSO-d $\mathrm{d}_{6}$ ): $\delta 4.34$ (s, 2H, $\mathrm{CH}_{2}$ ), 7.26-7.93 (m, 5H, thiazol \& $\mathrm{ArH}$ ), 8.08 (s, $1 \mathrm{H}, \mathrm{CH}$ of imidazole); ${ }^{13} \mathrm{C}$ NMR (125 MHz, DMSO- $d_{6}$ ): $\delta 35.52,110.30,123.60,129.21,130.05$, 130.95, 131.46, 132.04, 132.65, 134.32, 148.90, 155.45; MS $\mathrm{m} / \mathrm{z}, 293\left(\mathrm{M}^{+}\right), 295(\mathrm{M}+2)$. Anal. Calc. for $\mathrm{C}_{12} \mathrm{H}_{8} \mathrm{ClN}_{3} \mathrm{O}_{2} \mathrm{~S}$ : C, 49.07; H, 2.75; N, 14.31; S, 10.92. Found: C, 48.88; H, 2.62; N, 14.47; S, 10.77 .

6-(4-Chloro-3-nitrobenzyl)imidazo[2,1-b][1,3]thiazole (4f)

IR (KBr) $v_{\max } / \mathrm{cm}^{-1}: 1530,1350 ;{ }^{1} \mathrm{H}$ NMR $(500 \mathrm{MHz}$, DMSO-d $\mathrm{d}_{6}$ ): $\delta 4.13$ (s, 2H, $\mathrm{CH}_{2}$ ), 7.25-7.95 (m, 5H, thiazol 
\& $\mathrm{ArH}), 8.02$ (s, 1H, CH of imidazole); ${ }^{13} \mathrm{C}$ NMR (125 MHz, DMSO- $\left.d_{6}\right): \delta 34.95,109.85,127.02,129.12,129.95$, 130.64, 131.14, 134.87, 135.56, 135.98, 148.80, 154.48; MS $\mathrm{m} / 2.293\left(\mathrm{M}^{+}\right), 295(\mathrm{M}+2)$. Anal. Calc. for $\mathrm{C}_{12} \mathrm{H}_{8} \mathrm{ClN}_{3} \mathrm{O}_{2} \mathrm{~S}$ : C, 49.07; H, 2.75; N, 14.31; S, 10.92. Found: C, 49.23; H, $2.90 ; \mathrm{N}, 14.45 ; \mathrm{S}, 10.81$.

\section{Acknowledgments}

The authors would like to thank the Research Council of Shahrood University of Technology for the support of this work.

\section{References}

1. Moore, J. S.; Acc. Chem. Res. 1997, 30, 402; Hiyama, T. In Metal-Catalyzed Cross-Coupling Reactions; Diederich, F.; Stang, P. J., eds.; Wiley-VCH: Weinheim, 1998, ch. 10; Sonogashira, K.; J. Organomet. Chem. 2002, 653, 46; Sonogashira, K. In Handbook of Organopalladium Chemistry for Organic Synthesis; Negishi, E., ed.; Wiley-VCH: New York, 2002; Tykwinski, R. R.; Angew. Chem., Int. Ed. 2003, 42, 1566; Negishi, E.-J.; Anastasia, L.; Chem. Rev. 2003, 103, 1979.

2. Acetylene Chemistry; Stang, P. J.; Diederich, F.; Tykwinski, R. R., eds.; VCH: Weinheim, 2004, ch. 2; Modern Arene Chemistry; Astruc, D., ed.; Wiley-VCH: Weinheim, 2002, ch. 6 .

3. Brandsma, L.; Vasilevsky, S. F.; Verkruijsse, H. D.; Applications of Transition Metal Catalysts in Organic Synthesis; Springer: Berlin, 1988, ch. 10; Nicolaou, K. C.; Sorensen, E. J. Classics in Total Synthesis; Wiley-VCH: Weinheim, 1996, pp. 582; Graham, A. E.; McKerrecher, D.; Davies, D. H.; Taylor, R. J. K.; Tetrahedron Lett. 1996, 37, 7445; Miller, M. W.; Johnson, C. R.; J. Org. Chem. 1997, 62, 1582; Sakai, A.; Aoyama, T.; Shioiri, T.; Tetrahedron Lett. 1999, 40, 4211; Yoshimura, F.; Kawata, S.; Hirama, M.; Tetrahedron Lett. 1999, 40, 8281; Toyota, M.; Komori, C.; Ihara, M.; J. Org. Chem. 2000, 65, 7110; Paterson, I.; Davies, R. D. M.; Marquez, R.; Angew. Chem., Int. Ed. 2001, 40, 603; Uenishi, J.-I.; Matsui, K.; Ohmiya, H.; J. Organomet. Chem. 2002, 653, 141.

4. Sonogashira, K. In Comprehensive Organic Synthesis; Trost, B. M.; Fleming, I., eds.; Pergamon: New York, 1991; vol. 3, pp. 521-549.

5. Chow, H.-F.; Wan, C.-W.; Low, K.-H.; Yeung, Y.-Y.; J. Org. Chem. 2001, 66, 1910.

6. Casalnuovo, A. L.; Calabrese, J. C.; J. Am. Chem. Soc. 1990, 112, 4324; Dibowski, H.; Schmidtchen, F. P.; Tetrahedron Lett. 1998, 39, 525; Kabalka, G. W.; Wang, L.; Namboodiri, V.; Pagni, R. M.; Tetrahedron Lett. 2000, 41, 5151; Bong, D. T.; Ghadiri, M. R.; Org. Lett. 2001, 3, 2509; Mio, M. J.; Kopel,
L. C.; Braun, J. B.; Gadzikwa, T. L.; Hull, K. L.; Brisbois, R. G.; Markworth, C. J.; Grieco, P. A.; Org. Lett. 2002, 4, 3199; Remmele, H.; Köllhofer, A.; Plenio, H.; Organometallics 2003, 22, 4098 .

7. Fukuyama, T.; Shinmen, M.; Nishitani, S.; Sato, M.; Ryu, I.; Org. Lett. 2002, 4, 1691.

8. Okita, T.; Isobe, M.; Synlett 1994, 589; Nguefack, J.-F.; Bolitt, V.; Sinou, D.; Tetrahedron Lett. 1996, 37, 5527; Hundertmark, T.; Littke, A. F.; Buchwald, S. L.; Fu, G. C.; Org. Lett. 2000, 2, 1729; Netherton, M. R.; Fu, G. C.; Org. Lett. 2001, 3, 4295; Mery, D.; Heuzé, K.; Astruc, D.; Chem. Commun. 2003, 1934.

9. Powell, N. A.; Rychnosky, S. D.; Tetrahedron Lett. 1996, 37, 7901; Crisp, G. T.; Turner, P. D.; Stephens, K. A.; J. Organomet. Chem. 1998, 570, 219; Nakamura, K.; Ohubo, H.; Yamaguchi, M.; Synlett 1999, 549; Dai, W.-M.; Guo, D.-S.; Sun, L.-P.; Tetrahedron Lett. 2001, 42, 5275.

10. Uozumi, Y.; Kobayashi, Y.; Heterocycles 2003, 29, 1255 ; Leese, M. P.; Williams, J. M. J.; Synlett 1999, 1645; Bergbreiter, D. E.; Liu, Y.-S.; Tetrahedron Lett. 1997, 38, 7843; Lin, C.-A.; Luo, F.-T.; Tetrahedron Lett. 2003, 44, 7565; Djakovitch, L.; Rollet, P.; Tetrahedron Lett. 2004, 45, 1367; Tyrrell, E.; Al-Saardi, A.; Millet, J.; Synlett 2005, 487; Gonthier, E.; Breinbauer, R.; Synlett 2003, 1049; Novak, Z.; Szabo, A.; Repasi, J.; Kotschy, A.; J. Org. Chem. 2003, 68, 3327.

11. Parlow, J. J.; Mischke, D. A.; Woodard, S. S.; J. Org. Chem. 1997, 62, 5908; Valeury, E.; Bradley, M.; Tetrahedron 2007, 63, 8855; Mirkhani, V. ; Moghadam, M.; Tangestaninejad, S. ; Bahramian, B.; Polyhedron 2006, 25, 2904; Kang, Q.-X.; Luo, J.-J.; Bai, Y.-B.; Yang, Z.-W.; Lei, Z.-Q.; J. Organomet. Chem. 2005, 690, 6309; Chai, L.-T.; Wang, Q.-R.; Tao, F.-G.; J. Mol. Catal. A: Chem. 2007, 276, 137.

12. Andreani, A.; Granaiola, M.; Leoni, A.; Locatelli, A.; Morigi, R.; Rambaldi, M.; Lenaz, G.; Fato, R.; Bergamini, C.; Farruggia, G.; J. Med. Chem. 2005, 48, 3085; Andreani, A.; Rambaldi, M.; Locatelli, A.; Bossa, R.; Fraccari, A.; Galatulas, I.; J. Med. Chem. 1992, 35, 4634; Jaguelin, S.; Robert, A.; Gayral, P.; J. Med. Chem. 1991, 26, 51.

13. Yang, Y.-F.; Zhuang, M.; Zeng, C.-X.; Huang, C.-B.; Luo, M.-F.; Chin. J. Chem. 2006, 24, 1309.

14. Sonogashira, K.; Tohda, Y.; Hagihara, N.; Tetrahedron Lett. $1975,4467$.

15. Theron, F; Verry, M ; Vessiere, R. In The Chemistry of the Carbon-Carbon Triple Bond, Part I; Patai, S., ed.; J. Wiley \& Sons: Chichester, 1978, ch. 10, p. 381.

Received: September 20, 2008 Web Release Date: April 3, 2009 